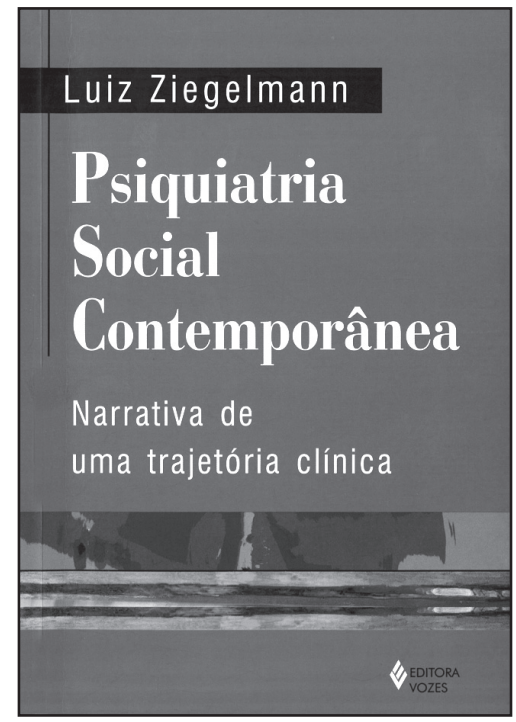

\section{Psiquiatria Social Contemporânea: Narrativa de uma Trajetória Clínica}

\author{
Luiz Ziegelmann \\ Editora Vozes, 2005
}

Luiz Ziegelmann é médico psiquiatra do Grupo Hospitalar Conceição, com especialização também em Saúde Pública, Educação e Medicina do Trabalho, e mestre em Psicologia Social. 0 livro organizado pelo autor chamou a atenção por sua clareza e pela forma como foi desenvolvido. Partindo de suas experiências e vivências, tanto comunitária, como hospitalar e de grupo, defrontou-se com a possibilidade de uma nova clínica em saúde mental dentro de uma perspectiva contemporânea, na qual enfatiza a ressignificação da clínica tradicional. Na narrativa, o autor relata sua preocupação com os conhecimentos que lhe foram passados durante os anos de faculdade, os quais, segundo ele, não foram suficientes para tornar inteligível o processo saúde/doença, uma vez que a clínica tradicional está voltada mais para os sinais e sintomas da doença do que especificamente para sua origem e, especialmente, sua produção. Isso fez com que fosse em busca de outras referências teóricas em diferentes campos do conhecimento.
Sua trajetória profissional em trabalho junto à comunidade lhe ofereceu possibilidades de um aprendizado voltado para a prática em saúde mais integrativa, participativa e crítica, proporcionando a construção de novas subjetividades e maneiras de existir com mais autonomia, valorizando a complexidade humana e vendo seu sofrimento como produção coletiva. 0 autor visualiza essa nova clínica, ou seja, a clínica grupal, a partir de seu percurso profissional, que teve início nos anos 1980, inicialmente como médico clínico numa experiência comunitária e, posteriormente, como psiquiatra em hospital geral. Sua sensibilidade é visível quando fala de suas inquietações e questionamentos, no momento em que depara com uma realidade tão complexa, como diz, para ele desconhecida. Do encontro com a comunidade e com as várias questões sociais inerentes à situação, começa a perceber a possibilidade do trabalho com grupos de moradores, acreditando no potencial que o coletivo é capaz de operar. Fala de uma nova clínica apoiada não somente na medicalização, mas, sim, na valorização dos sujeitos, buscando sua compreensão em suas dimensões ética, política e estética. Isso foi possível devido ao seu trabalho grupal, através das narrativas e análises das falas dos pacientes ao longo dos anos em contato com o grupo.

O livro consta de introdução e mais quatro capítulos, descrevendo sua trajetória clínica com detalhamento e numa seqüência de assunto bastante coerente e de interessante leitura. Portanto a obra é uma iniciativa louvável, demonstrando que a experiência da clínica grupal aponta para uma perspectiva de se caracterizar numa experiência que pode dar muito certo, transformando-se num dos instrumentos viáveis para a edificação de uma nova clínica em saúde mental.

José Carlos Souza

Psiquiatra; doutor em Saúde Mental pela Universidade Estadual de Campinas (UNICAMP); professor da Universidade Católica Dom Bosco (UCDB); Ph.D. pela Faculdade de Medicina de Lisboa

Neomar Souza

Psicóloga do Hospital Psiquiátrico Nosso Lar; mestranda em Psicologia pela UCDB 